\title{
From "Gomorrah Domain" to "Don Peppe Diana Lands". A Southern Italian Experience of Work-Based Liberation, Community Networking, and Well Being
}

\author{
Del "dominio de Gomorra" a "la Tierra de Don Peppe \\ Diana". Una experiencia de liberación en el sur de Italia a \\ través del trabajo de redes comunitarias y de bienestar
}

Recibido: marzo 4 de 2013 | Revisado: junio 1 de 2013 | Aceptado: septiembre 15 de 2013

\author{
Alfredo Natale* \\ CATERINA ARCIDIACONO ** \\ SALVATORE Di MARTINO *** \\ University of Naples Federico II, Italy
}

\section{Doi: 10.11144/Javeriana.UPSY12-4.fgtd}

Para citar este artículo: Natale, A., Arcidiacono, C., \& Di Martino, S. (2013). From "Gomorrah domain" to "Don Peppe Diana lands". A Southern Italian experience of work-based liberation, community networking, and well-being. Universitas Psychologica, 12(4), 1037-1047. Doi: 10.11144/Javeriana. UPSY12-4.fgtd

$\mathrm{PhD}$ student at the University of Naples Federico II, Italy.E-mail: alfredo.natale@unina.it

** Professor in Community Psychology at the University of Naples Federico II, Italy. Executive Committee of the European Community Psychology Association (ECPA).E-mail: caterina.arcidiacono@ unina.it

**** PhD student at the University of Naples Federico II, Italy. E-mail: Salvatore.dimartino@unina.it

\section{A B S T R A C T}

The article describes working experiences in relation to empowering activities, which have been carried out in a local community in the province of Caserta (in Southern Italy), a place characterized by the widespread presence of organized criminal groups. In this study, workplace is intended as a community network aimed at the promotion of coscientization, liberation, and well-being. Specifically, this paper features initiatives and projects aimed at establishing new community values through a re-construction of a work-based social system standing against criminal clans, which tend to dominate not only economical transactions but also civil life.

Key words authors

Network, social economy, conscientization, collective well-being.

Key words plus

Gomorrah, Criminal Power, De-Growth.

\section{RESUMEN}

El presente artículo describe el trabajo realizado mediante algunas actividades de empoderamiento desarolladas en una comunidad local de la provincia de Caserta (en el sur de Italia); un lugar que se caracteriza por la amplia presencia de la criminalidad organizada. El lugar de trabajo de este estudio está representado por una red comunitaria destinada a la promoción de la concientización, la liberación y el bienestar. De especial modo este trabajo se caracteriza por presentar iniciativas y proyectos dirigidos a establecer nuevos valores de comunidad a través de la reconstrucción de un sistema social basado en el trabajo y en contra de los grupos criminales, los cuales tienden a dominar no solo la actividad económica, sino también aspectos de la vida civil.

Palabras claves autores

Red, economía social, concientización, bienestar colectivo.

Palabras clave descriptores

Gomorra, poder criminal, decrecimiento. 


\section{Context from the Perspective of Liberation Psychology}

Liberation psychology as well as Community and Critical psychology teach us that context is not a mere backdrop, but it is the essential framework underpinning the whole "theatrical representation" where social actors play their part (Kloos at al., 2011; Kagan, Burton, Duckett, Lawthom, \& Siddiquee, 2011). If we refer to the etymology of the word "context" (from Latin: "con-textere", to weave together) we might better envisage the network between environmental and social relational connections, which intersect and reach every aspects of people's lives. Therefore, according to Liberation psychology, if we really want to liberate oppressed people, even at an individual level, working on the lives of individuals is utterly insufficient. Rather, it is necessary to change those political, economic, and public structures, which affect people and place them on a condition of inferiority, and hence, of suffering. The distinctive feature that characterizes the process of liberation is also found in the involvement of the psychologist within the context itself. In this sense, liberation cannot be considered as top-down assistance but, on the contrary, it is the fruit of a bottom-up commitment made by the psychologist and the oppressed people who are, as a consequence, actively engaged in their own liberation (Arcidiacono \& Di Martino, 2012).

The attention given by the Community psychologists to the importance of relationship for both research and action, is clearly highlighted by the liberation's philosophers Scannone $(1976,1990)$ and Dussel (1987, 1998). These authors "have defined an episteme of relatedness in which ontology rejects the dominant idea in Western thinking, of individuality as the essence of Being. That episteme considers that the Being resides in the relatedness in which all of us exist. Not because we cease to exist as individuals, but because we can only be individuals within the relations that we construct and that construct us" (Montero, 2011).

When Community psychologists also consider relationships in network terms, as it is the case here, the idea of community itself can be re-defined as "a unit of social organization consisting of overlapping personal network communities represented by relatively enduring social ties that routinely exhibit a high level of social interaction characterized by flows of resources" (Leighton, 1988, p. 359).

With this in mind, in this article we seek to show that the conceptualization and analysis of social networks has important connections with work (Voydanoff, 2001), social capital, and wellbeing (Cattell, 2001). In particular, we shall show how much a work-based networking community is able to re-construct social capital thereby promoting well-being.

\section{Local Context and Oppression}

First, we must outline the social, economic and political aspects of the area, where this project focuses on. The province of Caserta is a land located in the centre of Southern Italy, within the area once known by the ancient Roman Empire as "Campania Felix" (fertile countryside). Nowadays, this area has begun to evolve into the poorest area within the region of Campania, with the lowest GNP rate per capita ${ }^{1}$. Although, in the last few years, the province of Caserta has gradually developed various business activities in the agricultural, industrial, and public sector, a series of historical, social, and economic factors have allowed the emergence of some criminal organisations. Among these, it stands out in particular the "Casalesi Clan", which have found here a fertile soil in which to settle down (Anselmo \& Braucci, 2008; Di Fiore, 2010; Saviano, 2007). Over the past decade, the Casalesi Clan have shown themselves as one of the most powerful and dangerous criminal organizations in the World, although it still remains virtually unknown outside this region. Only in the last few years, in particular thanks to the great success of the book "Gomorrah" written by the journalist and writer Roberto Saviano (2007), it has been possible to recognise the national and international implications of the actions perpetrated by this criminal organisation.

1 Rapporto unioncamere: www.milanofinanza.it/news/dettaglio news.asp?id 
This clan is characterized by its specific organisational and pervasive capacity for infiltrating numerous economic, institutional, and political settings; this is also recognized by presenting a "criminal multiform hybrid" capacity, a combination of half camorra and half mafia, that has made possible to extend its dominion over a large physical area and over increasing social contexts (Sales \& Ravveduto, 2006). In particular, this criminal organisation is defined as an "entrepreneurial camorra" due to its ability to seep into the legal economy thereby controlling diverse productive sectors such as: construction, waste disposal, commerce, etc. It's political and economically pervasive control is mainly exercised through invisible forms of management of the construction market (protection rackets, control of public building contracts, imposition of production rules, purchasing of services and merchandise, control of the workforce). This same mechanism holds true in relation to the management of its manufacturing, agricultural, and commercial activities, not to mention the influence that this type of organized crime has on public contracts and tenders on employment within the public sector.

All these elements have led to a strong collusion between the economy, labor markets, and the political arena. Therefore, in those areas where this type of "criminal business organisation" acts the whole social, relational and commercial activities end up being ruled by subtle powers, which by managing the labour market, represent a form of governance, resulting in psycho-social oppression. These investments in "legal economy" serve to conceal the integration of criminal groups into the social fabric, in order to achieve social consensus. However, the use of illegal assets has polluted the market rules and has triggered, as a consequence, a series of detrimental mechanisms for local and national socio-economic development (Mosca \& Baldascino, 2012; Santino, 1995, 2006). Thus, the sociocultural context depicted, stands out as a dynamic of power that is non-generative of well-being, and has negative effects upon social capital (Roseland, 2000), resulting in dysfunctional relational asymmetries for community wellness, social injustice, and oppression. From the perspective of Liberation Psychology this domination has "naturalised" a social relational system aimed at perpetrating dynamics of power, which are based on competition, violence and prevarication (Martín-Barò, 1989).

As well as the local and national press, the sociological literature has repeatedly pointed out that the Mafia presence in the political and economic arena has compromised the organisation of the whole community system (Capacchione, 2010; Di Fiore, 2010) re-defining social capital, resources, opportunities, values, and even its social identities. Thus, the domination of this system by criminals has compromised the autonomy of individuals and the community at large. Such psychological subjection functions to safeguard local nuclei of power, which constitutes the dominant economic system which people depend on. The social and working system in this area has been ruled for decades by these - more or less - recognisable powers, which are founded upon the systematic use of violence and are centred on the pursuit of personal interest and the accumulation of wealth. The combination of these two factors has, over time, profoundly damaged the quality of life and the state of the environment of the province of Caserta to such an extent that even the welfare of future generations is now at risk.

\section{Resistence to Power}

Along with criminal oppression, some forms of resistance have marked the history of the Province of Caserta. Within a complex framework of opportunities, risks and possible contradictions, the local community has undertaken strategies and actions aimed at improving people's life within the community. These have been basically grounded on ethical values, which act in opposition to those that are generative of oppression.

In fact during the past decades, in conjunction with the development of criminal organisations, a resistance (hence liberation-oriented action) to Mafia power has flourished with individuals, groups, and institutions, working in different ways to combat this oppression. They are increasingly organising togeth- 
er and have taken a stand against this criminality by working on the destructuration and reconstruction of the entire community, and creating new relational and infrastructure models aimed at pursuing community well-being (Iorio, 2009; Solino, 2011).

In this light, the central crux of the entire psycho-social process of change lies in a new way of using those resources which belong to both individuals and the community at large. The relational and power-based relationships, which have so far dominated the local social life in the province of Caserta have been instead characterised by community capabilities, resources, and opportunities used in the "spirit of clan", hence aiming at private and individualistic ends. The alternative to that consists then in inverting such a process by redefining the ends with which local resources are used (not only material resources but also relational and cultural ones). This is possible only if individuals' collective interests as well as their differences are respected, protected, and valued; in other words, if these elements are embedded in a wider community perspective (Morin, 2011) by constructing and reconstructing new identifications.

\section{Social Identity between Oppression and Liberation}

The condition of oppression experienced in the province of Caserta has, over time, marked the identity of the whole community life to such an extent that it is now essential to work on the community itself to produce any possible change. The values and culture established through violence and oppression have created a basis of social identification, which is made up of elements that are felt to be inseparable from the community's identity, which has been compromised by disrespectful selfishness. Indeed, a "criminal root" of social identity seems to stand out from this context, which causes conflict and resistance to legality and respect for social norms. On this account, it is worth revisiting Martín-Barò's reasoning, according to which liberation from oppression does not only come down to conquering a land, but also to constructing a social identity (Martín-Barò, 1989, p. 71).
In this particular context, people's actions carried out on the working system and the labor market, in order to promote their own well-being, have been going hand in hand with a symbolic redefinition of their territory. The province of Caserta is, in fact, well-known and recognised as "Gomorrah land" (or Camorra land). This denomination, used for the first time by Roberto Saviano, has been turned into "Don Peppe Diana land" thereby turning this Priest's name (who was killed by one of camorra clans) into a symbol of the fight for redemption.

This changing in the collective imaginary, from the use/reuse of names, has been the result of a reconstruction of social capital, as well as physical and social structures, values and rules, which define relationships, symbolic contexts, and untold elements that influence community identity (Natale, 2013). In this particular case, it is worth noting that the criminal organisation worldwide recognized as the "Casalesi Clan" shares its name with Casal di Principe's citizens (whom are named, indeed, casalesi).

This overlap in names led this place to be wrongly defined and put the seal on people who have always been related to this criminal clan. Casal di Principe's citizens claim, indeed, their distance from all this by means of the slogan "Casalesi is a citizens' name" which represents their will to change and their desire for liberation.

In that sense, re-defining these places expresses an action of conscientization, which does not deny the grim reality of camorra but, on the contrary, recognises it in order to make a change. In this way, it is possible to acknowledge and value those positive and pro-social aspects, which are present in this context, even though they may still be unknown.

\section{Redefinition of Names and Meanings}

Fals Borda (1979) proposes action research as an instrument for sharing and educating people through transformative knowledge. The redefinition of names as a way of redefining meanings within a local context is, therefore, one of the tools used here. In the province of Caserta, as just mentioned, this 
was brought forward by the civil society through a reappropriation and reconversion of names, which in the past have represented (and in part they still do) elements connected to criminal organisations hence to a dynamic of oppression.

Along with this attempt to define and increasingly redefine this territory as "Don Peppe Diana Lands", and highlighting the community identity through names, values, and features of those who have opposed the Mafia, we shall here recall some work-based initiatives also aimed at transforming the symbolic universe of this community.

But first, we need to start from a little premise. The entire process, which we shall describe soon, is framed within the Italian law n. 109/96, which allows for the utilisation of assets confiscated from the Mafia for social ends. However, this social use can reach its full symbolic value only once these assets are no longer defined as "confiscated" (indicating in that way an expropriation of something that used to belong to an owner, even if illegitimate), but "liberated" from Mafia power, thereby being given back to the community as community assets.

With particular reference to this, it is worth showing here a social cooperative experience aimed at the inclusion of disadvantaged people in the labour market (under the Italian law n. 381/91), which brought to life a restaurant-pizzeria called N.C.O. This acronym resembles the name of "Nuova Camorra Organizzata" (New Organised Camorra) created by Mafia boss Raffaele Cutolo, but in reality it stands for "Nuova Cucina Organizzata" (New Organised Cookery). This capacity to tease criminal powers is a way of delegitimating and disempowering its destructivity. At the same time, it shows also the will of people to transform this power in order to generate social bonds that will be of service to the entire community. Another experience of a social business, whose name characterizes its value-based dimension, is an ethnic tailor shop run by a group of African women who make Italian fashion creations of African fabrics. These women gave life to a new fashion brand called "Made in Castel Volturno". Castel Volturno is a city usually known as a place in which drug dealing, prostitution, and urban, social, and cultural degradation abound, and where the massive presence of African migrants is accounted for as the cause of every social problem.

The possibility of making high fashion by valuing the importance of intercultural richness comes to oppose the image of the stranger as an enemy, thereby making it an economic and cultural resource for the development of the whole community. In the light of this strategy aimed at transforming the symbolic reference of places and realities, the project has been named "Let's dress freedom up".

Last but not least, the initiative "Let's make a pack $^{2}$ to camorra" is discussed as a means by which a number of local networking associations have put on the market several Christmas hampers to use as gifts, which have been filled with diverse agricultural and craft products produced in Don Peppe Diana lands. The idea is to "make a pack to camorra", which recalls the well-know Neapolitan scam. This time, however, the "pack" is metaphorically made against camorra, in order to hit this at a symbolic, as well as an economic level.

We would like to propose here a last symbolic reconversion, which more and more organisations and citizens are gaining awareness of. This is the promotion of the denomination used to refer to those who have been subjected to Mafia wrongdoings from "Mafia victims" to "partisans" new denomination, in fact, opens up a new semiotic perspective since this is a way, not only to commemorate those who have been subjected to violence or died, but also a way to celebrate and hence promote resistance to criminal powers. This is a way to remind us that although this fight has left martyrs and heroes on the battlefield, it has also produced, over time, significant changes

2 Within Neapolitan culture, "to make a pack" means to set up a particular kind of scam where a crook offers an unaware victim a normally very expensive product (usually technological accessories) at a very affordable price. Often with the aid of an accomplice, the crook distracts the victim for a few seconds, which is enough time for the crook to pretend to pack the product while, in reality, it gets swapped with a fake one. The "pack" is so wellknown in Naples in which it has become part of the common parlance to indicate every kind of scam.

3 Italian partisans (antifascist guerrilla fighters) were freedom fighters who aided the Allied battle against the Germans. They were part of The Italian Resistance, which had been fighting against the fascist government of Mussolini and the Nazi government of Hitler. 
with the power to eventually transform the whole community. This transformation refers to the idea of a subject that is no longer seen as defeated and bent by the criminal power and oppression but as an active fighter as well as bearer and promoter of collective well-being.

The social resignification, witnessed in the province of Caserta is in line with the process that the French scholar Serge Latouche called decolonization of the imaginary, which in turn fosters the well-known De-growth paradigm $(2010,2011)$. In fact, the latter obliges us to question the concepts of social justice, freedom, health, welfare and is, therefore, in accordance with both the practices of conscientization proposed by Liberation psychology and Critical Community psychology (Aron \& Corne, 1994; Montero \& Sonn, 2009; Vaughan, 2011).

\section{Networking as a Transformative Tool}

This study focuses on a different and definitely more complex conception of workplace, which is not only understood as site of work. The former is, in fact, the outcome of a widespread, yet organised, social network aimed at promoting coscientization, liberation, well-being, and transformation of the community framework. We might say that here network represents, at the same time, both a much broader place of work where people bring into play their workforce and a powerful instrument to change the workplace itself from the grassroots. In the province of Caserta, although the diverse instances of social change, which have opposed mafia power, have different histories, origin, dynamics, and objectives (Gelardi, 2009, 2011; Sardo, 2008; Solino, 2011), they have become, over the years, increasingly organised into broad organisational structures aimed at radical change within the local community. Their shared aims have been to improve quality of life and promote social justice and fairness. These are becoming increasingly known and active, while gaining a social role and a definite identity affirming this new way of living in community. Some second level associations (associations of associations), in particular "Don Peppe Diana committee" operat- ing at a local level and "Libera Associations, names and numbers against Mafias" operating at a national level, encompass and coordinate the different forces which are represented by citizens, cooperatives, associations, and institutional authorities actively involved in contrasting camorra, while promoting cultural change and collective well-being.

According to Critical Community Psychology, these complex transformative spurs can be considered as useful instruments for improving community's quality of life (Campbell, Cornish, \& Mclean, 2004). The construction of partnerships and productive relationships is, in fact, essential to reach shared and superordinate goals. In fact, "Community psychologists bring skills in group facilitation, conflict mediation, and team building that are vitally important in establishing shared values and goals, and in building consensus about how to achieve those values and goals" (Nelson, Prilleltensky, \& MacGillivary, 2001, p. 657).

\section{Involvement in the Context and Participation, from a Community Psychology Perspective}

Human freedom is expressed not in the denial of oppression but in a real life-sustaining generative power, which takes place in as much as a creative capacity for producing solid community ties, developed both at a local and at a global level. Only by means of identity processes and collective subjectivity it is, in fact, possible to overcome the individualistic and materialistic attachment to private property (Natale, 2013).

Similarly, the promotion of a network as a dialogical tool of coscientization aimed at community thriving is possible in as much as a Community psychologist actively takes part in the network itself, by sharing values, objectives, and intervention methodologies (Arcidiacono, 2009). According to the participatory action-research model (Reason \& Bradbury, 2008) the psychologist participates, together with the people involved through the process of co-construction of meaning and in negotiation of intervention's aims and objectives. In doing so, the psychologist then becomes a "territorial socio- 
political catalyst" thanks to its immersion in the context.

In this way, the Community psychologist takes part in the dialogue between the social actors involved and contributes to scientific competence and knowledge of the development of the intersubjective dialogic process. In the same vein, the Community psychologist is actively involved in promoting people's participation in decision-making. In an owner or management dominated workplace (which can clearly be the case of the province of Caserta) worker decision-making is normally highly restricted. If it is true, as held by Barker and Martin (2011) and in more general terms by Frey and Stutzer (2002), that democracy and participation in decision-making processes are a by-product of happiness, any intervention aimed at removing the obstacles which stand in the way of active civil participation ought to be paramount.

\section{Fair Trade Economy and Social Networks: The RES Project}

As Mosca reminds us, the actions perpetuated by criminal organization transform rights into concessions, into favors, which must be reciprocated, which, in turns, generate enslaved and conditioned individuals. Therefore, in those social contexts, where the influence of criminality is strong, it is necessary to weaken the determinant of social consensus. That means breaking a vicious circle of social and cultural impoverishment, and a developmental model underpinned by criminality itself (Mosca \& Villani, 2010).

One of the possible ways out of oppression is represented through the promotion of organizations operating in the field of social and civil economy. These social outcome-oriented organisations are grounded on values such as solidarity, cohesion, social responsibility, democracy, participation, and autonomy. In the province of Caserta, for example, a social network of fair trade economy has been consolidating over time. In 2012 this network started an integrated project funded by "Fondazione con il Sud" bank, and the Department of Hu- manities (University of Naples Federico II) actively participated in it.

Of the thirty partners involved in the project there were many different types of organisations, including: associations, cooperatives, local authorities, and Universities. All of them have joined up to contrast organized criminality and foster social development. The fruit of this cooperation was "Rete di Economia Sociale" (Social Economic Network) that is the RES project. The RES project was aimed at a reorganisation of community social capital through the development of local solidarity and the transformation of sociocultural-economic processes. Specifically the project aimed to activate cooperative production in places and buildings confiscated from organised crime (under the Italian law n. 109/96) so as to promote governance, shared outcomes and strategic actions that respect the environment and the health of people. The social net gained by this became an opportunity for experimenting new forms of conviviality as well as a place in which to develop negotiated community norms and critical consciousness.

Specifically the RES project focused on five main goals:

- Promoting and implementing social economic practices from a networking perspective through the use of assets, which have been confiscated/liberated from camorra.

- Promoting people's freedom with particular attention to those who are more disadvantaged.

- Promoting respect for cultural diversity in order to build educational and cooperating communities.

- Valuing the best practices of social inclusion and innovative actions of welfare; and

- Making the actions of public administration available, transparent, and accountable for citizens in order to foster local sustainable development and fight against organised criminality.

The wider objective was, thus, to give value to the existing territorial resources, the social network 
that has grown in the recent years (associations, cooperatives, etc.), the earth, the cost, the assets confiscated/liberated from mafia, the intercultural richness, and to do all of this through using those tools and structures in tune with the principles of social economy. Occupational activities which build social cohesion, through immaterial other than material frameworks, were also used.

In this account, the RES project is consistent with the idea of sustainable community, that is a community "that uses its resources to meet current needs while ensuring that adequate resources are available for future generations" (World Commission on Environment and Development, 1987, p. 43). In this sense, the RES development stressed the importance of striking a balance between environmental concerns and development objectives while simultaneously enhancing local social relationships (Bridger \& Luloff, 2001).

The RES project also hinged on the five distinctive features that support a sustainable community proposed by Bridger and Luloff (1999) (Increasing local economic diversity, self-reliance, reduction in energy use, protection and enhancement of biological and environmental diversity, social justice), and on the six forms of "community capital" described by Mark Roseland (2005) (Natural, Phsysical, Economic, Human, Social, and Cultural capital).

The future of the RES project lies within sectoral agri-food chains, sustainable tourism, and social building which are currently underway. At the same time, there is the attempt to promote cultural, economical, and political relationships between firms, territorial/extra-territorial co-operations, and local operators. Moreover, since this territory involves a high percentage of seasonal working migrants, with the majority being illegal, a territorial pact between institutional authorities and the civil society promoting interculturality and a better use of public services in favour of migrants is already in the making. Finally, there is the intention of supporting public administration by setting up a social budget, which will make available, transparent, and valuable the social actions and traceability of public expenditure; all of this will be aimed at guaranteeing sustainable local development in contrast to the waste of public resources that have happened elsewhere.

The RES project will undertake other actions in the lens of Community and Critical Psychology allowing further processes of coscientization and occupational inclusion to take place. This project has the development of a sustainable tourist chain aimed at giving value to environmental and community resources as its vision. These paths of sustainable tourism are also aimed at fostering encounters and socialisation between people. The relational exchange helps the local community to recognize its subjectivity starting from its ethical values of welcoming, solidarity, and respect for cultural diversity. Another purpose is to make people aware of the historical, social, cultural, and environmental beauties that have been hidden by past oppression.

Another kind of psycho-social-oriented change is the creation and promotion of an Agency of social communication for the development of "communicative activity" to be at the service of the entire community network. This agency will produce and manage the whole web platform for the RES project upgrading information and integrated communication. The platform will also be used to share educational and multimedia files related to the project and the social action that the latter brings into bear.

A database of memory and commitment to the project will also be created. This will be an archive of stories of resistance to camorra and civic commitment. In an intercultural perspective, there is the intention to digitalise various materials such as video, photos, documents, among others, in order to preserve the memory of past generations and also the ones of the migrants with regard to those crucial themes related to the community. This work will eventually bring to life two multimedial museums, one called "Museum of Cultures" and the other one called "Museum of Resistance". The aim is to enable people to remember, know, and value the stories that marked "Don Peppe Diana lands" within a process of collective memory. In oder to build such a project, the involvement of local people and many others is suggested. 
As we pointed out elsewhere, the outcome of the RES project is the development of new and more complex social identities characterised by mutual respect and dialogue with the Other and the environment. This initiative has been developed through a contract network based on shared ethical values, which in turn supports local businesses production and consumption, as well as those political choices made by the organisations involved. As previously mentioned, this alternative community started from a process of collective reconceptualisation of collective imaginary by symbolically transforming Caserta territories' reference from "Gomorrah domain" to "Don Peppe Diana lands". This new way of looking at production and consumption fosters the overcoming of an egocentric and materialistic vision, which instead, promoted solely individual interests.

\section{Final Remarks: A New Vision of Work and Power}

In this article we suggested that in order to promote work-based liberation it is necessary to share a circular relationship among all the actors involved in this process, which must be dialectic, reciprocallyoriented, and participatory focused. In this regard, a liberation-oriented Community psychology plays, among other things, a fundamental role in promoting inter-individual and group dialogue, which is aimed at developing relational networks and collective well-being. In particular the attention paid to work is focused here on its capacity to generate satisfying social relationships, which are suitable not for the market's sake but for the growth of humans and their relation with the surrounding environment. The working product is, in that sense, a relational good and not a material commodity because the whole production is aimed at creating conviviality and social generativity (Scabini \& Manzi, 2011).

The example of the province of Caserta tells us that shared objectives and visions led the development of partnership and the success of social actions. A shared networking action, instead, acted as a keystone for the process of change and liberation from oppression.

Networking and partnership also played an important role for the process of coscientization of the community itself. Networking has been, in fact, the underpinning of the relational framework upon which a process of change and re-elaboration of the context at large could be built. This implied redefining social categorisations and community identification. This has been, thus, the backbone of the entire process, which led to an increased awareness of the forces that were at stake.

Through shared and work-based networking activities it has been possible for the citizens of the province of Caserta to oppose not only the power of organised crime, but also to shield themselves from the unbridled forces of globalisation. By means of these social tools they managed to change their social fabric and ground community life upon co-operation and trust. Liberation, in this context, acted as a proxy for a better collective working experience, co-living, and social cohesion. The network underway in the province of Caserta is, in that sense, an experiment of destructuring the asymmetries of local and global power. In this framework, the shift from working competition to co-operation, which intends to deeply modify the relationship between work, workers, work-place, and context, sets economics and society free from the rigid laws of the neo-liberal market thereby generating new social bonds and collective well-being.

\section{References}

Anselmo, M., \& Braucci, M. (2008). Questa corte condanna: Spartacus, il processo al clan dei casalesi. Napoli: L'Ancora del Mediterraneo.

Arcidiacono, C. (2009). Riflessività, processualità, situatività: parole chiave della ricerca-azione. Ricerche di Psicologia, 32(3-4), 113-126.

Arcidiacono, C., \& Di Martino, S. (2012). Psicologia della liberazione e psicologia critica di comunità come conquista di felicità, libertà ed equità. Rivista di Psicologia di Comunità, 8(1), 67-80. 
Aron, A. \& Corne, S. (Eds.). (1994). Ignacio MartínBaró. Writings for a liberation psychology. Cambridge: Harvard University Press.

Barker, C., \& Martin, B. (2011). Participation: The happiness connection. Journal of Public Deliberation, 7(1), Article 9. Available at http://www.publicdeliberation.net/jpd/vol7/iss1/art9

Bridger, J., \& Luloff, A. E. (1999). Toward an interactional approach to sustainable community development. Journal of Rural Studies, 15(4), 377-387.

Bridger, J. C., \& Luloff, A. E. (2001). Building the sustainable community: Is social capital the answer? Sociological Inquiry, 71(4), 458-472.

Campbell, C., Cornish, F., \& McLean, C. (2004). Social capital, participation and the perpetuation of health inequalities: Obstacles to African-Caribbean participation in 'partnerships' to improve mental health. Ethnicity Gु Health, 9(3), 305-327.

Capacchione, R. (2010). L'oro della camorra. Milano: Rizzoli.

Cattell, V. (2001). Poor people, poor places, and poor health: The mediating role of social networks and social capital. Social Science EO Medicine, 52(10), 1501-1516.

Di Fiore, G. (2010). L'impero dei casalesi: Traffici, storie e segreti dell'occulta e potente mafia dei casalesi. Milano: Rizzoli.

Dussel, E. (1987). Accessos hacia una filosofía del la liberación. Buenos Aires: La Aurora.

Dussel, E. (1998). La ética de la liberación. México: UNAM.

Fals Borda, O. (1979). The problem of investigating reality in order to transform it. Dialictical Anthropology, 4(1), 33-56.

Frey, B. S., \& Stutzer, A. (2002). Happiness and economics: How the economy and institutions affect human well-being. Princeton: Princeton University Press.

Gelardi, M. (Ed.). (2009). La ferita. Pollena, Napoli: Ad Est dell'Equatore.

Gelardi, M. (Ed.). (2011). La giusta parte. Testimoni e storie dell'antimafia. Napoli: Caracò.

Iorio, P. (2009). Il Sud che resiste: storie di lotta per la cultura della legalità in Terra di Lavoro. Roma: Ediesse.

Kagan, C., Burton, M., Duckett, P., Lawthom, R., \& Siddiquee, A. (2011). Critical community psychol- ogy: Critical action and social change. West Sussex, UK: John Wiley \& Sons.

Kloos, B., Hill, J., Thomas, E., Wandersman, A., Elias, M. J., \& Dalton, J. H. (2011). Community psychology. Linking individuals and communities. Belmont, CA: Wadsworth.

Latouche, S. (2010). Growth, recession, or degrowth for sustainability and equity? [Special Issue]. Journal of Cleaner Production, 18(6), 519-522. doi: 10.1016/j. jclepro.2010.02.003

Latouche, S. (2011). Vers une société d'abondance frugale: Contresens et controverses de la décroissance. Paris: Fayard/Mille et une nuits.

Leighton, B. (1988). The community concept in criminology: Toward a social network approach. Journal of Research in Crime and Delinquency, 25(4), 351-374.

Martín-Baró, I. (1989). Retos y perspectivas de la psicología latinoamericana. In G. Pacheco \& B. Jiménez (Eds.), Ignacio Martín-Baró (1942-1989). Psicología de la liberación para América Latina (pp. 51-79). Guadalajara: Universidad de GuadalajaraITESO.

Montero, M. (2011, June). From complexity and social justice to consciousness: Ideas that have constructed community psychology. Paper presented at the International Community Psychology: Community Approaches to Contemporary Social Problems, Puebla, México.

Montero, M., \& Sonn, C. C. (2009). Psychology of liberation: Theory and applications. New York: Springer.

Morin, E. (2011). La voie: Pour l'avenir de l'humanité. Paris: Fayard.

Mosca, M., \& Baldascino, M. (2012). Sussidiarietà orizzontale, welfare comunitario ed economia sociale. Napoli: De Frede.

Mosca, M., \& Villani, S. (2010). L'impresa sociale ed il riutilizzo a fini sociali dei beni confiscati: verso un nuovo modello di sviluppo del Mezzogiorno fondato sul capitale sociale e sul "territorio". Impresa Sociale, 79(3), 33-50.

Natale, A. (2013). Potere, identità sociale e benessere. Il pensiero della decrescita nell'incontro con le scienze umane. In C. Arcidiacono (Ed.), Benessere e felicità (pp. 59-79). Napoli: Diogene Edizioni. 
Nelson, G., Prilleltensky, I., \& MacGillivary, H. (2001). Building value-based partnerships: Toward solidarity with oppressed groups. American Journal of Community Psychology, 29(5), 649-677. doi: 10.1023/a:1010406400101

Reason, P., \& Bradbury, H. (Eds.). (2008). The Sage handbook of action research: Participative inquiry and practice (2nd. ed.). London: Sage.

Roseland, M. (2000). Sustainable community development: Integrating environmental, economic, and social objectives. Progress in Planning, 54(2), 73-132. doi: 10.1016/s0305-9006(00)00003-9

Roseland, M. (2005). Toward sustainable communities: Resources for citizens and their governments. Gabriola Island, BC: New Society Publishers.

Sales, I., \& Ravveduto, M. (2006). Le strade della violenza: Malviventi e bande di camorra a Napoli. Napoli: L'Ancora del Mediterraneo.

Santino, U. (1995). La mafia interpretata. Dilemmi, stereotipi, paradigmi. Messina: Rubbettino.

Santino, U. (2006). Dalla mafia alle mafie: scienze sociali e crimine organizzato. Messina: Rubbettino.

Sardo, R. (2008). La bestia. Camorra. Storie di delitti, vittime e complici. Milano: Melampo.
Saviano, R. (2007). Gomorrah (V. Jewiss, Trans.). London: Pan Macmillan UK.

Scabini, E., \& Manzi, C. (2011). Identity in family processes. In S. J. Schwartz, K. Luyckx \& V. L. Vignoles (Eds.), Handbook of identity theory and research (pp. 569-588). New York: Springer.

Scannone, J. C. (1976). La liberatión latinoamericana. In J. C. Scannone (Ed.), Teologia de la liberación y praxis popular. Salamanca: Sígueme.

Scannone, J. C. (1990). Nuevo punto de partida en la filosofía latinoamericana. Buenos Aires: Guadalupe.

Solino, G. (2011). La Buona Terra. Storie dalle terre di don Peppe Diana. Molfetta, BA: La Meridiana.

Vaughan, C. (2011). Dialogue, critical consciousness and praxis. In D. Hook, B. Franks \& M. W. Bauer (Eds.), The social psychology of communication (pp. 46-66). Basingstoke, England: Palgrave Macmillan.

Voydanoff, P. (2001). Conceptualizing community in the context of work and family. Community, Work Eg Family, 4(2), 133-156.

World Commission on Environment and Development. (1987). Our common future. New York: Oxford University Press. 
